medRxiv preprint doi: https://doi.org/10.1101/2021.05.21.21257546; this version posted May 28, 2021. The copyright holder for this preprint

(which was not certified by peer review) is the author/funder, who has granted medRxiv a license to display the preprint in perpetuity.

All rights reserved. No reuse allowed without permission.

\title{
Independent and combined effects of nutrition and sanitation interventions on child growth in rural Cambodia: a factorial cluster-randomized controlled trial
}

\author{
Amanda Lai ${ }^{1}$, Irene Velez ${ }^{2}$, Ramya Ambikapathi ${ }^{3}$, Krisna Seng $^{2}$, Oliver Cumming $^{4}$, Joe Brown ${ }^{5}$ \\ ${ }^{1}$ School of Civil and Environmental Engineering, Georgia Institute of Technology, Atlanta, \\ Georgia, USA \\ ${ }^{2}$ MSI, A Tetra Tech Company, Arlington, Virginia, USA \\ ${ }^{3}$ Department of Public Health, Purdue University, West Lafayette, Indiana, USA \\ ${ }^{4}$ Department of Disease Control, Faculty of Infectious and Tropical Diseases, London School of \\ Hygiene and Tropical Medicine, London, UK \\ ${ }^{5}$ Department of Environmental Sciences and Engineering, Gillings School of Global Public \\ Health, University of North Carolina at Chapel Hill, Chapel Hill, North Carolina, USA
}


medRxiv preprint doi: https://doi.org/10.1101/2021.05.21.21257546; this version posted May 28, 2021. The copyright holder for this preprint (which was not certified by peer review) is the author/funder, who has granted medRxiv a license to display the preprint in perpetuity.

All rights reserved. No reuse allowed without permission.

\begin{abstract}
Background

Childhood exposure to fecal pathogens contributes to growth faltering, which is linked with adverse side effects later in life. The prevalence of stunting remains high in rural Cambodia, despite rapid economic development over the last two decades. This study aimed to assess the independent and combined effects of nutrition and sanitation programming on child growth outcomes in rural Cambodia.
\end{abstract}

Methods

We conducted a factorial cluster-randomized controlled trial of 4,015 households with 4,124 children (1-28 months of age) across rural Cambodia. Fifty-five communes (clusters) were randomly assigned to a control arm or one of three treatments: a nutrition-only arm, a sanitationonly arm, and a combined nutrition and sanitation arm receiving both treatments. The primary outcome was length-for-age Z-score (LAZ). Secondary outcomes were weight-for-age Z-score (WAZ), weight-for-height Z-score (WHZ), stunting, wasting, underweight, and caregiverreported diarrhea. Analysis was by intention-to-treat. The trial was pre-registered with ISRCTN Registry (ISRCTN77820875).

\title{
Findings
}

Compliance in the arms receiving the nutrition intervention was high, but compliance in the arms receiving the sanitation intervention was low. Compared with a mean LAZ of -1.04 (SD 1.2) in the control arm, children in the nutrition-only arm (LAZ +0.08, 95\% CI: $-0.01-0.18)$ and combined nutrition and sanitation arm (LAZ $+0.10,95 \% \mathrm{CI}: 0.01-0.20)$ experienced greater linear growth; there were no measurable differences in LAZ in the sanitation-only arm. Similarly, compared with a mean WAZ of -1.05 (SD 1.1) in the control arm, children in the nutrition-only arm (WAZ $+0.10,95 \%$ CI 0.00-0.19) and combined-intervention arm (WAZ $+0.11,95 \%$ CI $0.03-0.20$ ) were heavier for their age; there was no measurable difference in WAZ in the sanitation-only arm. There were no differences between arms in prevalence of stunting, wasting, underweight status, or one week period prevalence of diarrhea.

\section{Interpretation}

Improvements in child growth in nutrition and combined nutrition and sanitation arms are consistent with other recent trials but we found no evidence that this sanitation intervention improved child growth. The sanitation intervention achieved only modest changes in sanitation access and use suggesting that more effective approaches are needed to reduce open defecation in this setting.

Funding

United States Agency for International Development (USAID). The contents of this publication are the sole responsibility of the authors and do not necessarily reflect the views of USAID or the United States Government. 
medRxiv preprint doi: https://doi.org/10.1101/2021.05.21.21257546; this version posted May 28, 2021. The copyright holder for this preprint

(which was not certified by peer review) is the author/funder, who has granted medRxiv a license to display the preprint in perpetuity.

All rights reserved. No reuse allowed without permission.

\section{Background}

Childhood undernutrition is associated with higher risk of infectious disease morbidity and mortality, reduced cognitive function, and various adverse outcomes later in life ${ }^{1}$. Growth faltering is an effect of chronic undernutrition, and tends to be concentrated in the first two years of life ${ }^{2}$. The relationship between breastfeeding and overall good nutrition and undernutrition is well understood ${ }^{3,4}$, and, consequently, many studies have focused on improving infant and child nutrition to achieve better growth outcomes ${ }^{5-7}$. However, these interventions alone have not been successful in eliminating stunting ${ }^{5}$, suggesting that broader interventions which address other important factors are needed alongside exclusive breastfeeding and improved nutritional intake . $^{8}$ Reducing early childhood exposure to infectious agents through safe water, sanitation, and hygiene (WASH) is one such potentially important complimentary intervention.

WASH plausibly reduces undernutrition ${ }^{9}$ by at least three important pathways: diarrheal diseases, intestinal worm infections, and subclinical gut damage ${ }^{10}$. First, diarrhea is attributable to inadequate $\mathrm{WASH}^{11}$ and is both a cause and effect of undernutrition because children with diarrhea absorb fewer nutrients, possibly leading to further susceptibility to infections ${ }^{12}$. The risk of stunting has been estimated to increase multiplicatively with each diarrheal episode before 24 months of age ${ }^{13}$. Second, infection by soil-transmitted helminths (e.g., Ascaris, Trichuris, or hookworm) from fecal-contaminated soil - common where WASH is inadequate - can lead to anemia, poor absorption of nutrients, and other effects on gut health including impaired digestion and diarrhea ${ }^{14}$. Finally, there is evidence that chronic exposure to enteric pathogens may result in changes to gut structure and function described as environmental enteric dysfunction (EED). EED is characterized in part by chronic inflammation, reduced nutrient absorption, and weakened barrier function of the small intestine ${ }^{15,16}$, although the pathogenesis of EED and the mechanism by with faltered growth occurs are yet to be defined ${ }^{1716,17}$

Among WASH interventions, sanitation as a means to reducing stunting has received significant attention in the last decade. Many observational studies have found strong associations between child growth faltering and poor access to sanitation studies in Cambodia ${ }^{18}$, Indonesia ${ }^{19}$, and India ${ }^{20}$. However, recent randomized controlled trials (RCTs) in Zimbabwe ${ }^{21}$, Bangladesh ${ }^{6}$, and $\mathrm{Kenya}^{7}$ that delivered standalone household-level sanitation interventions (not coupled with other nutrition or hygiene interventions) were not found to improve child growth.

The community-led total sanitation (CLTS) framework is a relatively new approach to ending open defecation through behavioral change and community self-enforcement rather than through the provision of hardware and materials ${ }^{22}$. CLTS and other rural promotion-based interventions shift the focus from individual and household sanitation practices to a community-level concern over open defecation by triggering collective behavior change through powerful emotional drivers such as shame and disgust, as well as positive motivators such as improved healthy, dignity, and pride ${ }^{23,24}$. Observational studies in Cambodia ${ }^{25}$, India ${ }^{26}$, Ecuador ${ }^{27}$ and elsewhere ${ }^{28,29}$ found higher community-level sanitation coverage to be associated with reduced prevalence of stunting. Despite this, recent RCTs employing promotion-based interventions have found mixed effects on child growth. One trial was found to be successful in improving child growth in Mali $^{30}$, but this effect was not observed in other trials in Tanzania ${ }^{31}$, Indonesia ${ }^{32}$, nor India ${ }^{33,34}$. 
medRxiv preprint doi: https://doi.org/10.1101/2021.05.21.21257546; this version posted May 28, 2021. The copyright holder for this preprint (which was not certified by peer review) is the author/funder, who has granted medRxiv a license to display the preprint in perpetuity.

All rights reserved. No reuse allowed without permission.

Here, we add to a growing literature to evaluate the impact of combined nutrition and sanitation interventions on children growth. We used a factorial cluster-randomized controlled trial (cRCT) to assess the independent and combined effects of nutrition and sanitation interventions delivered in the context of a large-scale, USAID-funded rural nutrition and sanitation/hygiene program in Cambodia. We hypothesized that children receiving both sanitation and nutrition interventions would have increased linear growth compared with children from control areas. We further hypothesized that combined nutrition and sanitation interventions would lead to synergistic improvements in linear growth beyond that realized in either standalone intervention arm.

\section{Methods}

\section{Study setting and population}

We employed a two-by-two factorial cluster-randomized controlled trial in rural communes in three provinces in Cambodia: Battambang, Pursat, and Siem Reap. The target communes had at least $30 \%$ of the population living below the poverty line and did not have latrine subsidies in place at the time of intervention. Of a list of 82 eligible communes, 27 were excluded as pilot activities had already been launched, and the remaining 55 target communes were randomly assigned to one of three treatment arms ( $\mathrm{n}=36$ communes) or control arm ( $\mathrm{n}=19$ communes). The number of communes assigned to the control arm (19 versus 12 communes in each treatment arm) was greater to enhance statistical efficiency of multiple hypothesis testing ${ }^{35}$ (Figure 1).

\section{Randomization and masking}

In 2015, prior to the start of project activities, we randomly assigned the communes to one of three treatment arms (nutrition only, sanitation/hygiene only, combine nutrition and sanitation/hygiene) or control arm using a random number generator with reproducible seed in Stata (Stata, College Station, TX). Randomization was conducted at a cluster level to limit the risk of contamination between study arms. All villages within each treatment commune received the assigned interventions for their respective commune. Allocation was communicated directly to Save the Children and Foundation of Netherlands Volunteers (SNV), who rolled-out interventions based on this randomized assignment. Following randomization, three communes were dropped from the trial due to objections from the local governments of overlap with other current programming. This resulted in 55 communes with treatment arms of different sizes: 11 communes in nutrition-only arm; 13 in sanitation-only arm; 12 in combined-intervention arm (Figure 1). Neither participants nor field staff were masked to treatment status due to the nature of the interventions. Participants were not told about other communes receiving interventions, and field staff did not discuss the trial with participants. The data collection team was blinded to the treatment assignment, number of treatment arms, and knowledge of a control arm.

\section{Interventions procedures}

The intervention was delivered in the 36 intervention communes over the course of two years, between 2015-2017, while the remaining 19 control communes were unexposed to the program. Two international non-governmental organizations - Save the Children and SNV - provided programmatic implementation and coordinated activities with local governments.

The nutrition interventions included complementary feeding activities and education through community-based growth promotion sessions, caregiver groups, home visits, and conditional cash transfers (CCTs) linked to the utilization of key health and nutrition services focusing on 
medRxiv preprint doi: https://doi.org/10.1101/2021.05.21.21257546; this version posted May 28, 2021. The copyright holder for this preprint (which was not certified by peer review) is the author/funder, who has granted medRxiv a license to display the preprint in perpetuity.

All rights reserved. No reuse allowed without permission.

first 1,000 days of life. The sanitation interventions consisted primarily of CLTS as it was delivered here, latrine vouchers coupled with supply-side support for sanitation and hygiene products, and social behavior change communications (SBCC). Intervention activities are summarized in Table 1 below and detailed in Supplemental Information.

Table 1: Summary of intervention activities

\begin{tabular}{|c|c|c|}
\hline & Intervention activity & Frequency \\
\hline \multicolumn{3}{|l|}{ NUTR } \\
\hline & $\begin{array}{l}\text { Community dialogues led by village chief and VHSG to } \\
\text { support children's growth }\end{array}$ & Quarterly \\
\hline & $\begin{array}{l}\text { Caregiver group sessions led by local women trained by } \\
\text { staff to promote } 13 \text { key stunting prevention behaviors }\end{array}$ & Monthly \\
\hline & $\begin{array}{l}\text { GMP sessions led by VHSGs to monitor growth and refer } \\
\text { children who were sick or not growing well to health } \\
\text { centers }\end{array}$ & Monthly \\
\hline & $\begin{array}{l}\text { Home visits to pregnant women, caregivers of children 9- } \\
11 \text { months old, and caregivers of children not growing } \\
\text { well to promote childcare and feeding, home hygiene, } \\
\text { latrine, and handwashing }\end{array}$ & Monthly \\
\hline & $\begin{array}{l}\text { Village fair help twice per year to offer hands-on learning } \\
\text { experiences (health/nutrition, WASH and agricultural } \\
\text { using games, latrine marketing and sales }\end{array}$ & Twice per year \\
\hline & $\begin{array}{l}\text { CCT (cash for antenatal and postnatal care visits and } \\
\text { adherence to handwashing stations), vouchers for water } \\
\text { filters and food baskets }\end{array}$ & $\begin{array}{l}\text { Up to six payments over first } 1,000 \text { days } \\
\text { of child life }\end{array}$ \\
\hline \multicolumn{3}{|l|}{ SAN } \\
\hline & CLTS triggering session & Once \\
\hline & $\begin{array}{l}\text { Door-to-door visits to provide information about } \\
\text { sanitation/latrines }\end{array}$ & At least five times per village \\
\hline & $\begin{array}{l}\text { Latrine vouchers to subsidize poor households in villages } \\
\text { that reached } 75 \% \text { sanitation coverage to achieve sufficient } \\
\text { open defecation free (ODF) coverage }\end{array}$ & Once, as needed \\
\hline & $\begin{array}{l}\text { Promoted supply-side support by connecting small- and } \\
\text { medium-sized enterprises (SMEs) with communes after } \\
\text { triggering event }\end{array}$ & Continuously \\
\hline \multicolumn{3}{|c|}{ NUTR+SAN } \\
\hline & All activities described in NUTR and SAN groups above & See above \\
\hline \multicolumn{3}{|l|}{ CTRL } \\
\hline & None & $\mathrm{N} / \mathrm{A}$ \\
\hline
\end{tabular}

Enumerators completed in-home interviews with the primary caregiver of children in the household using a survey which based the majority of questions on validated Cambodia DHS questionnaires. Field staff asked caregivers questions about basic household member information; health and diet of children up to age 28 months; hygiene, water and sanitation practices; pregnancies and child births of the caregiver; intervention exposure and participation; household WASH conditions, and household assets/characteristics to build wealth scores. 
medRxiv preprint doi: https://doi.org/10.1101/2021.05.21.21257546; this version posted May 28, 2021. The copyright holder for this preprint

(which was not certified by peer review) is the author/funder, who has granted medRxiv a license to display the preprint in perpetuity.

All rights reserved. No reuse allowed without permission.

\section{Data collection}

Final measurements took place in August 2019, 28 months after the end of the roll-out period. The trial enrolled primary caregivers with a child that was born during or after time of exposure to the interventions ( $1-28$ months at time of our study) and who had lived in the commune during the child's entire life, resulting in a participant population of children 1-28 months old. Data collection was completed by KHANA Center for Population Health Research, with oversight and support from Management Systems International (MSI).

All surveys were communicated in the Khmer language. A primary survey was conducted to assess household and child-level risk factors of children under 28 months of age. Enumerators completed in-home interviews with the primary caregiver of children in the household about basic household member information; breastfeeding and nutrition of children up to age 28 months; hygiene, water and sanitation practices; pregnancies and child births of the caregiver; intervention exposure and participation; household WASH conditions; and household assets/characteristics to construct wealth scores. Child height and weight were measured by trained paired enumerators following guidelines from the Food and Nutrition Technical Assistance project (FANTA) ${ }^{36}$; measurement protocols are described in detail in Supplemental Information $^{37}$.

For nutrition-related data collection, we included the infant and young children feeding indicators suggested by the World Health Organization (WHO), which include minimum dietary diversity, minimum meal frequency, and minimum adequate $\operatorname{diet}^{38}$. WHO dietary diversity score consists of categorizing solid foods into seven food groups, including: grains, legumes/nuts, dairy, flesh meat, eggs, vitamin-A-rich fruits and vegetables, and other fruits and vegetables. To suit the Cambodian context, the evaluation team asked additional questions on the types of fish and other wild animals consumed, which are included in the flesh meat group. The dietary diversity score is on a scale from $0-7$ and determined based on the number of food groups the caregiver reported to have fed the child in the last 24 hours; minimum dietary diversity is defined as having received food from four or more food groups (or a dietary diversity score greater than or equal to four). Minimum meal frequency is defined by the frequency of solid and semi-solid foods received based on a child's age and whether the child is breastfed. The minimum number of times breastfed children should receive solid, semi-solid, or soft foods varies with age (2 times if 6-8 months and 3 times if 9-23 months). The minimum number of times non-breastfed children should receive solid, semi-solid, or soft foods, including milk, is 4 times for all children 6-23 months.

As part of a supplemental analysis to assess the effects of key community-level WASH indicators, a secondary survey was conducted in households randomly selected in the same areas (three households per village) and irrespective of whether there was a child living in the household. Given the oversampling of households with children under 28 months of age, poststratification weights were used to get a representative sample of the population. Sampling weights were calculated as follows: first, we estimated the proportion of households with children under 28 months of age at the village-level by creating a list of eligible children with the village chief and VHSG. This estimate was then divided by the proportion of sampled households with children under 28 months of age at each village to yield the sampling weight for each household from the main sample. For the three additional households, the sampling weights 
medRxiv preprint doi: https://doi.org/10.1101/2021.05.21.21257546; this version posted May 28, 2021. The copyright holder for this preprint (which was not certified by peer review) is the author/funder, who has granted medRxiv a license to display the preprint in perpetuity.

All rights reserved. No reuse allowed without permission.

were calculated by dividing the remaining proportion of total households at the village level by the proportion of sampled households at each village. This resulted in underweighting the households with children under 28 months of age and overweighting the supplemental households.

\section{Outcomes}

The primary outcome was length-for-age Z-score (LAZ) at (timepoint). Secondary outcomes were weight-for-age Z-score (WAZ), weight-for-height Z-score (WHZ), caregiver reported diarrhea; proportion of children stunted (LAZ<-2), underweight (WAZ $<-2)$, and wasted $(\mathrm{WHZ}<-$ 2); and all-cause mortality.

\section{Statistical analysis}

We performed an intention-to-treat (ITT) analysis for all outcomes using generalized estimating equations to account for clustering at the village level. We used ordinary least squares linear regression to estimate mean differences between treatment arms compared to the control arm and between standalone treatment arms compared to the combined treatment arm for LAZ, WAZ, and WHZ. We used Poisson regression to estimate the prevalence ratio between arms for diarrhea, stunting, wasting, and underweight status.

Sample size was chosen to balance the size of the study and the minimum detectable difference between arms. Power calculations used $\alpha=0.05$, power $=0.8$, mean LAZ estimate (prior to intervention rollout) of -0.96 with a standard deviation of 1.19 , intra-cluster correlation of 0.014 on the LAZ outcome measure at the commune level, and a two-sided test for a two-sample comparison of means. LAZ calculations used a standard equation assuming a single, posttreatment measurement at 2 years, resulting in a total of 4,015 households consisting of 73 observations per commune. These sample size calculations suggest that this study had sufficient power to detect a minimum detectable effect size (MDES) of 0.19 for differences in the LAZ scores between treatment arms and a MDES of 0.18 for differences between each treatment arm and the control arm. An MDES of 0.19 translates to a $23.4 \%$ change in LAZ score between treatment $\mathrm{arms}^{39}$; an MDES of 0.18 translates to a $22.2 \%$ change in LAZ scores between treatment and control arms. While empirical evidence to serve as an adequate basis for the MDES was limited, the WASH-Benefits efficacy trial set its sample size to detect a similar LAZ MDES of 0.18 between treatment arms and a MDES of 0.15 in mean LAZ scores between treatment and control arms ${ }^{6,7}$.

Covariates were considered as potential confounders using a "common cause" approach ${ }^{40}$ and on the basis of the conceptual framework of variables correlated with diet and WASH conditions as well as nutritional status ${ }^{9}$. We also considered covariates that were found to be both significantly associated with primary outcome measures and imbalanced across treatment arms before intervention delivery, of which only pre-intervention village-level sanitation coverage met the criteria (Supplemental Information). We calculated household wealth using an asset-based wealth index using methodology provided by the Demographic and Health Survey (DHS) ${ }^{37}$, constructed using principal component analysis excluding WASH assets ${ }^{41}$. In the adjusted analyses, we included the following covariates, identified a priori: child sex (dichotomous), child age (continuous, in months), maternal age (continuous, in years), maternal education (ordinal, based on mother's highest level of education attended), number of household members 
medRxiv preprint doi: https://doi.org/10.1101/2021.05.21.21257546; this version posted May 28, 2021. The copyright holder for this preprint (which was not certified by peer review) is the author/funder, who has granted medRxiv a license to display the preprint in perpetuity.

All rights reserved. No reuse allowed without permission.

(continuous), household wealth index quintile (ordinal), and community-level open defecation (OD) measured at prior to intervention rollout (continuous).

\section{Role of the funding source}

This study was funded by USAID. USAID had no role in study design, data collection, data analysis, data interpretation, or writing of the manuscript. The contents of this publication are the sole responsibility of the authors and do not necessarily reflect the views of USAID or the United States Government.

\section{Ethics}

The study received approval from the National Ethics Committee for Health Research in the Cambodian Ministry of Health, Georgia Institute of Technology, and New England Institutional Review Board. Prior to any data collection, the trial was explained to participants in the Khmer language. Written and verbal consent were obtained prior to administering the surveys and anthropometry measurements. The trial was pre-registered with ISRCTN Registry (ISRCTN77820875).

ResultsTable 2 shows household and caregiver characteristics across treatment and control groups. Most were similar across groups. Primary caregivers in the control group reported lower levels of primary school attendance compared to the treatment groups, but paternal primary school attendance was similar. Households in the nutrition-only and sanitation-only groups had higher wealth (ex-WASH) index scores compared to households in the combined intervention and control groups. The survey was conducted during the rainy season, which generally represents increased access to an improved source of drinking water. The control group had a higher prevalence of improved water source as their main source of drinking water compared to the treatment groups.

Figure 1 shows the flow diagram through the phases of the trial. Details about participant inclusion and exclusion can be found in Supplemental Information. 4,015 households participated in endline surveys; 4,005 households were included in these analyses (10 were excluded due to incomplete surveys), and 4,124 children had anthropometry measures taken. 
medRxiv preprint doi: https://doi.org/10.1101/2021.05.21.21257546; this version posted May 28, 2021. The copyright holder for this preprint (which was not certified by peer review) is the author/funder, who has granted medRxiv a license to display the preprint in perpetuity. All rights reserved. No reuse allowed without permission.

Table 2: Household and caregiver characteristics

\begin{tabular}{|c|c|c|c|c|c|c|c|c|}
\hline & \multicolumn{2}{|c|}{ Nutrition-only } & \multicolumn{2}{|c|}{ Sanitation-only } & \multicolumn{2}{|c|}{ Combined } & \multicolumn{2}{|c|}{ Control } \\
\hline & Mean & $95 \% \mathrm{CI}$ & Mean & $95 \% \mathrm{CI}$ & Mean & $95 \% \mathrm{CI}$ & Mean & $95 \% \mathrm{CI}$ \\
\hline Buddhist & 0.98 & $(0.97,0.99)$ & 0.97 & $(0.96,0.98)$ & 0.96 & $(0.95,0.97)$ & 0.99 & $(0.98,0.99)$ \\
\hline Married or living together & 0.95 & $(0.93,0.96)$ & 0.94 & $(0.92,0.95)$ & 0.94 & $(0.92,0.95)$ & 0.95 & $(0.94,0.96)$ \\
\hline Maternal age (years) & 32.0 & $(31.2,32.7)$ & 31.1 & $(30.4,31.9)$ & 31.9 & $(31.2,32.5)$ & 31.0 & $(30.5,31.5)$ \\
\hline $\begin{array}{l}\text { Primary caregiver has } \\
\text { attended primary school }\end{array}$ & 0.87 & $(0.85,0.89)$ & 0.87 & $(0.84,0.89)$ & 0.88 & $(0.85,0.89)$ & 0.81 & $(0.79,0.83)$ \\
\hline $\begin{array}{l}\text { Spouse has attended } \\
\text { primary school }\end{array}$ & 0.90 & $(0.88,0.92)$ & 0.86 & $(0.83,0.88)$ & 0.87 & $(0.85,0.89)$ & 0.87 & $(0.85,0.89)$ \\
\hline Household size & 5.63 & $(5.48,5.78)$ & 5.54 & $(5.40,5.69)$ & 5.36 & $(5.24,5.47)$ & 5.52 & $(5.42,5.62)$ \\
\hline Number of children in $\mathrm{HH}$ & 2.61 & $(2.52,2.70)$ & 2.61 & $(2.51,2.70)$ & 2.43 & $(2.36,2.50)$ & 2.43 & $(2.37,2.49)$ \\
\hline Has electricity & 0.73 & $(0.70,0.76)$ & 0.74 & $(0.71,0.77)$ & 0.76 & $(0.73,0.78)$ & 0.75 & $(0.72,0.77)$ \\
\hline Owns a mobile phone & 0.93 & $(0.92,0.95)$ & 0.90 & $(0.88,0.92)$ & 0.87 & $(0.85,0.89)$ & 0.90 & $(0.89,0.92)$ \\
\hline Has a finished floor [1] & 0.92 & $(0.90,0.94)$ & 0.93 & $(0.91,0.95)$ & 0.96 & $(0.94,0.97)$ & 0.96 & $(0.95,0.97)$ \\
\hline $\begin{array}{l}\text { Wealth (ex-WASH) index } \\
\text { score }\end{array}$ & 0.06 & $(-0.06,0.19)$ & 0.19 & $(0.05,0.33)$ & -0.02 & $(-0.14,0.09)$ & -0.12 & $(-0.21,-0.03)$ \\
\hline $\begin{array}{l}\text { Improved drinking water } \\
\text { source [2] }\end{array}$ & 0.59 & $(0.56,0.62)$ & 0.56 & $(0.52,0.59)$ & 0.61 & $(0.58,0.64)$ & 0.70 & $(0.68,0.72)$ \\
\hline Has water source on site & 0.68 & $(0.64,0.71)$ & 0.58 & $(0.55,0.61)$ & 0.60 & $(0.57,0.63)$ & 0.65 & $(0.62,0.67)$ \\
\hline $\begin{array}{l}\text { Water source is }<5 \mathrm{~min} \text {, } \\
\text { roundtrip }\end{array}$ & 0.20 & $(0.16,0.25)$ & 0.23 & $(0.19,0.28)$ & 0.24 & $(0.19,0.29)$ & 0.34 & $(0.29,0.39)$ \\
\hline $\begin{array}{l}\text { Reported minutes to fetch } \\
\text { water, roundtrip }\end{array}$ & 12.42 & $(10.6,14.2)$ & 14.14 & $(12.5,15.8)$ & 14.50 & $(13.1,15.9)$ & 13.56 & $(12.3,14.8)$ \\
\hline
\end{tabular}

[1] Finished floor defined as floor made of wood plans, palm/bamboo, parquet or polished wood, vinyl or asphalt strips, ceramic tiles, cement tiles, or cement. Floor materials were classified by enumerator observation. [2] Improved sources of drinking water include: piped water into dwelling/yard/plot, public tap or standpipe, tube well or borehole, protected dug well, protected spring, bottled water, and rainwater.

Nutrition intervention fidelity was high, with households in the nutrition-only and combinedintervention arms reporting significantly higher participation in these activities compared to the sanitation-only and control groups (

Table 3). Fidelity was measured based on self-reported participation in eight key nutrition activities: community dialogues (quarterly); caregiver group education course (monthly); village fairs (bi-annually); growth monitoring program (monthly); home health visits from VHSG (monthly); CCT with rolling enrollment (disbursed payments as participants met the various conditions); food vouchers (delivered once to CCT participants); and water filter vouchers (delivered once to CCT participants). Approximately 60\% of households in the nutrition-only and combined-intervention arms reported participating in at least four of the eight nutrition intervention activities, compared to $4 \%$ in the sanitation-only and control arms. Conversely, sanitation intervention fidelity was very low (

Table 3), which was measured by self-reported CLTS participation. Only $6 \%$ of households in the sanitation-only and control arms reported participating in any CLTS activity, compared to $14 \%$ of households in the nutrition-only arm and $25 \%$ in the combined-intervention arm. 


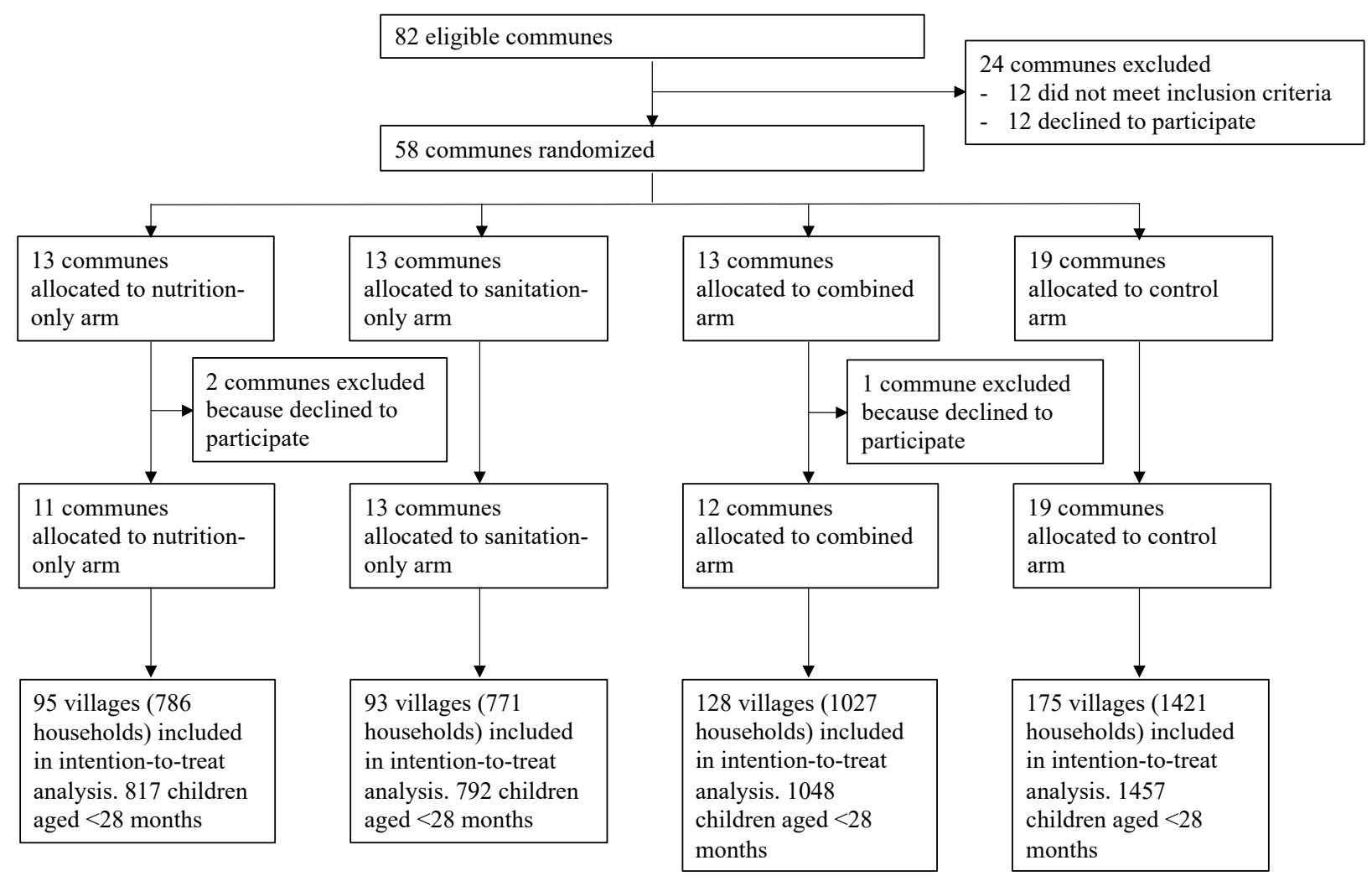

Figure 1: Trial profile

Intervention compliance were assessed 28 months after the intervention (Table 4). More households in the control arm (70\%) had an improved water source as their main source of drinking water, compared to other arms (approximately 60\% in all arms). The combined intervention arm had greater access to improved sanitation facilities (61\%) compared to the nutrition-only (55\%) sanitation-only (51\%), and control (52\%) arms. OD was practiced less in the combined intervention arm (7\%) compared to the nutrition-only (14\%), sanitation-only $(16 \%)$, and control (16\%) arms. Notably, the sanitation-only arm experienced a significantly higher increase in sanitation coverage $(+25 \%)$ compared to all other arms $(+14 \%$ in nutritiononly arm, $+19 \%$ in combined and control arms). We assessed four key caregiver behaviors related to environmental hygiene: drink and use clean water, handwashing with soap and water at critical times, proper disposal of children's stools, and provision of safe play environments for children. Implementation programming encouraged safe handwashing behaviors as part of the "First 1,000 Days" activities and the nutrition CCT. Those in the nutrition-only arm (7\%) and combined-intervention arm $(9 \%)$ had greater awareness of critical handwashing times compared to those in the sanitation-only arm (4\%) and control arm (4\%), though levels were still low. There was slightly higher prevalence of soap and water observed at handwashing stations in the combined-intervention (72\%) and control (76\%) arms than the nutrition-only $(69 \%)$ and sanitation-only (70\%) arms. Proper disposal of children's stools includes discarding into a toilet/latrine or burying; improper disposal practices include discarding feces into a drain, garbage or other solid waste, or leaving in the open. Nutrition-only and combined intervention arms reported higher levels of proper disposal (71\% and $74 \%$, respectively) compared to the sanitation-only and control arms (65\% and 68\%, respectively). Few households were found to have safe play environments, defined as being free of observed human feces, animal feces, 
garbage/household waste, and sharp objects/other harms. $25 \%$ of households in the combined intervention arm had child play environments free of feces observed by enumerators at the time of the household visit, compared to $21 \%$ in the nutrition-only, sanitation-only, and control arms. More households in the nutrition-only (78\%) and combined-intervention (89\%) arms brought children to health centers for monthly GMP visits than sanitation-only (23\%) and control (33\%) arms. There were no differences in breastfeeding behaviors between intervention and control arms, with $60-70 \%$ of each arm reporting continuous breastfeeding for children for the first two years. There were no statistically meaningful differences in dietary diversity score, minimum dietary diversity, and minimum meal frequency across the four arms. A theory of change diagram is included in Supplemental Information.

Table 3: Intervention fidelity indicators

\begin{tabular}{|c|c|c|c|c|c|c|c|c|c|c|c|c|}
\hline \multirow[b]{2}{*}{ Nutrition } & \multicolumn{3}{|c|}{ Nutrition-only } & \multicolumn{3}{|c|}{ Sanitation-only } & \multicolumn{3}{|c|}{ Combined } & \multicolumn{3}{|c|}{ Control } \\
\hline & $\mathrm{N}$ & $\mathrm{n}$ & $\%$ & $\mathrm{~N}$ & $\mathrm{n}$ & $\%$ & $\mathrm{~N}$ & $\mathrm{n}$ & $\%$ & $\mathrm{~N}$ & $\mathrm{n}$ & $\%$ \\
\hline $\begin{array}{l}\text { Participated in any "First } \\
1,000 \text { Days" type activity [1] }\end{array}$ & 817 & 615 & $75 \%$ & 792 & 145 & $18 \%$ & 1,055 & 813 & $77 \%$ & 1,460 & 383 & $26 \%$ \\
\hline Participated in any GMP & 817 & 641 & $78 \%$ & 792 & 181 & $23 \%$ & 1,055 & 935 & $89 \%$ & 1,460 & 482 & $33 \%$ \\
\hline Received home visit VHSG & 817 & 518 & $63 \%$ & 792 & 227 & $29 \%$ & 1,055 & 661 & $63 \%$ & 1,460 & 490 & $34 \%$ \\
\hline $\begin{array}{l}\text { Enrolled in any CCT program } \\
\text { for health and nutrition [2] }\end{array}$ & 817 & 224 & $27 \%$ & 792 & 19 & $2 \%$ & 1,055 & 228 & $22 \%$ & 1,460 & 31 & $2 \%$ \\
\hline $\begin{array}{l}\text { Received any voucher for } \\
\text { food basket [3] }\end{array}$ & 817 & 440 & $54 \%$ & 792 & 1 & $0 \%$ & 1,055 & 554 & $53 \%$ & 1,460 & 6 & $0 \%$ \\
\hline $\begin{array}{l}\text { Received any voucher for } \\
\text { water filter }\end{array}$ & 817 & 41 & $5 \%$ & 792 & 40 & $5 \%$ & 1,055 & 149 & $14 \%$ & 1,460 & 100 & $7 \%$ \\
\hline $\begin{array}{l}\text { Aware of Grow Together } \\
\text { campaign [4] }\end{array}$ & 817 & 353 & $43 \%$ & 792 & 93 & $12 \%$ & 1,055 & 471 & $45 \%$ & 1,460 & 149 & $10 \%$ \\
\hline $\begin{array}{l}\text { Participation in nutrition } \\
\text { intervention activities: none } \\
(0 \text { of } 8)\end{array}$ & 817 & 65 & $8 \%$ & 792 & 404 & $51 \%$ & 1,055 & 44 & $4 \%$ & 1,460 & 585 & $40 \%$ \\
\hline $\begin{array}{l}\text { Participation in nutrition } \\
\text { intervention activities: low } \\
(1-3 \text { of } 8)\end{array}$ & 817 & 262 & $32 \%$ & 792 & 359 & $45 \%$ & 1,055 & 367 & $35 \%$ & 1,460 & 809 & $55 \%$ \\
\hline $\begin{array}{l}\text { Participation in nutrition } \\
\text { intervention activities: med } \\
(4-6 \text { of } 8)\end{array}$ & 817 & 387 & $47 \%$ & 792 & 29 & $4 \%$ & 1,055 & 501 & $47 \%$ & 1,460 & 65 & $4 \%$ \\
\hline $\begin{array}{l}\text { Participation in nutrition } \\
\text { intervention activities: high } \\
(7-8 \text { of } 8)\end{array}$ & 817 & 103 & $13 \%$ & 792 & 0 & $0 \%$ & 1,055 & 143 & $14 \%$ & 1,460 & 1 & $0 \%$ \\
\hline \multicolumn{13}{|l|}{ Sanitation } \\
\hline Any CLTS participation [5] & 817 & 115 & $14 \%$ & 792 & 46 & $6 \%$ & 1,055 & 261 & $25 \%$ & 1,460 & 81 & $6 \%$ \\
\hline $\begin{array}{l}\text { Received any voucher to } \\
\text { build latrine [6] }\end{array}$ & 817 & 66 & $8 \%$ & 792 & 51 & $6 \%$ & 1,055 & 123 & $12 \%$ & 1,460 & 84 & $6 \%$ \\
\hline \multicolumn{13}{|c|}{$\begin{array}{l}\text { [1] "First 1,000 Days" activities were administered in nutrition-only and combined arms and include: community dialogues, } \\
\text { caregiver group education sessions, and village fairs. [2] CCT program ended in Jan } 2019 \text { and the Government of Cambodia } \\
\text { started a new CCT program in July } 2019 \text { across study area. CCT program administered in nutrition-only and combined arms } \\
\text { only. [3] Vouchers for water filter and food baskets were targeted subsidies distributed to CCT participants in nutrition-only } \\
\text { and combined arms. [4] Grow Together campaign was part of the nutrition programming (nutrition-only and combined arms). } \\
\text { However, three TV spots were seen across all four arms. [5] In sanitation-only and combined arms, the Ministry of Rural } \\
\text { Development confirmed that the project was the only CLTS campaign active in those areas. [6] Latrine vouchers were } \\
\text { targeted subsidies given to households in villages that reached 75\% sanitation coverage in sanitation-only and combined arms. }\end{array}$} \\
\hline
\end{tabular}


Table 4: Intervention compliance indicators (28-months after intervention)

\begin{tabular}{|c|c|c|c|c|c|c|c|c|c|c|c|c|}
\hline & \multicolumn{3}{|c|}{ Nutrition-only } & \multicolumn{3}{|c|}{ Sanitation-only } & \multicolumn{3}{|c|}{ Combined } & \multicolumn{3}{|c|}{ Control } \\
\hline Nutrition & $\mathrm{N}$ & $\begin{array}{l}\mathrm{n} \text { or } \\
\text { mean }\end{array}$ & $\begin{array}{l}\% \\
\text { or } \\
\text { SD }\end{array}$ & $\mathrm{N}$ & $\begin{array}{c}\mathrm{n} \text { or } \\
\text { mean }\end{array}$ & $\begin{array}{l}\% \\
\text { or } \\
\text { SD }\end{array}$ & $\mathrm{N}$ & $\begin{array}{c}\mathrm{n} \text { or } \\
\text { mean }\end{array}$ & $\begin{array}{l}\% \\
\text { or } \\
\text { SD }\end{array}$ & $\mathrm{N}$ & $\begin{array}{l}\mathrm{n} \text { or } \\
\text { mean }\end{array}$ & $\begin{array}{l}\% \text { or } \\
\text { SD }\end{array}$ \\
\hline $\begin{array}{l}\text { Visited health facility for at } \\
\text { least four antenatal care } \\
\text { check-ups }\end{array}$ & 697 & 632 & $91 \%$ & 712 & 646 & $91 \%$ & 910 & 819 & $90 \%$ & 1,257 & 1116 & $89 \%$ \\
\hline $\begin{array}{l}\text { Brought child for monthly } \\
\text { GMP at community or } \\
\text { health center }\end{array}$ & 817 & 641 & $78 \%$ & 792 & 181 & $23 \%$ & 1,055 & 935 & $89 \%$ & 1,460 & 482 & $33 \%$ \\
\hline $\begin{array}{l}\text { Breastfeeding exclusively } \\
\text { for children }<6 \text { months }\end{array}$ & 171 & 109 & $64 \%$ & 161 & 110 & $68 \%$ & 205 & 140 & $68 \%$ & 272 & 182 & $67 \%$ \\
\hline Ever breastfed (all children) & 817 & 797 & $98 \%$ & 792 & 765 & $97 \%$ & 1,048 & 1021 & $97 \%$ & 1,457 & 1420 & $97 \%$ \\
\hline $\begin{array}{l}\text { Solid and semi-solid foods } \\
\text { eaten for children }>6 \\
\text { months }\end{array}$ & 646 & 609 & $94 \%$ & 631 & 611 & $97 \%$ & 843 & 792 & $94 \%$ & 1,185 & 1134 & $96 \%$ \\
\hline Dietary diversity score (0-7) & 817 & 2.24 & 1.61 & 792 & 2.19 & 1.58 & 1,048 & 2.20 & 1.62 & 1,457 & 2.33 & 1.59 \\
\hline $\begin{array}{l}\text { Achieved minimum dietary } \\
\text { diversity }\end{array}$ & 817 & 202 & $25 \%$ & 792 & 177 & $22 \%$ & 1,048 & 247 & $24 \%$ & 1,457 & 350 & $24 \%$ \\
\hline $\begin{array}{l}\text { Achieved minimum meal } \\
\text { frequency }\end{array}$ & 817 & 537 & $66 \%$ & 792 & 518 & $65 \%$ & 1,048 & 680 & $65 \%$ & 1,457 & 977 & $67 \%$ \\
\hline $\begin{array}{l}\text { Achieved minimum } \\
\text { acceptable diet }\end{array}$ & 817 & 170 & $21 \%$ & 792 & 159 & $20 \%$ & 1,048 & 205 & $20 \%$ & 1,457 & 310 & $21 \%$ \\
\hline \multicolumn{13}{|l|}{ Sanitation } \\
\hline $\begin{array}{l}\text { Had improved sanitation } \\
\text { facility [1] }\end{array}$ & 816 & 452 & $55 \%$ & 791 & 400 & $51 \%$ & 1,054 & 638 & $61 \%$ & 1,459 & 759 & $52 \%$ \\
\hline Open defecation & 817 & 112 & $14 \%$ & 792 & 126 & $16 \%$ & 1,055 & 73 & $7 \%$ & 1,460 & 231 & $16 \%$ \\
\hline Used shared toilet & 817 & 252 & $31 \%$ & 791 & 264 & $33 \%$ & 1,054 & 343 & $33 \%$ & 1,459 & 468 & $32 \%$ \\
\hline $\begin{array}{l}\text { Caregiver reported adults in } \\
\text { HH openly defecating }\end{array}$ & 697 & 92 & $13 \%$ & 658 & 116 & $18 \%$ & 973 & 118 & $12 \%$ & 1,208 & 213 & $18 \%$ \\
\hline $\begin{array}{l}\text { Time to get to toilet, one } \\
\text { way (minutes) }\end{array}$ & 171 & 4.22 & 4.11 & 166 & 3.92 & 3.83 & 219 & 4.74 & 8.17 & 291 & 5.05 & 8.27 \\
\hline $\begin{array}{l}\text { Reported latrine built as a } \\
\text { result of CLTS activity }\end{array}$ & 115 & 51 & $44 \%$ & 46 & 15 & $33 \%$ & 261 & 91 & $35 \%$ & 81 & 28 & $35 \%$ \\
\hline $\begin{array}{l}\text { Reported latrine built using } \\
\text { latrine voucher }\end{array}$ & 50 & 10 & $20 \%$ & 15 & 4 & $27 \%$ & 91 & 37 & $41 \%$ & 28 & 12 & $43 \%$ \\
\hline $\begin{array}{l}\text { Main reason for not } \\
\text { constructing latrine: lack of } \\
\text { funds }\end{array}$ & 20 & 17 & $85 \%$ & 18 & 14 & $78 \%$ & 60 & 55 & $92 \%$ & 14 & 14 & $100 \%$ \\
\hline $\begin{array}{l}\text { Main reason for } \\
\text { construction latrine: privacy }\end{array}$ & 51 & 7 & $14 \%$ & 15 & 6 & $40 \%$ & 91 & 6 & $7 \%$ & 28 & 7 & $25 \%$ \\
\hline $\begin{array}{l}\text { Main reason for } \\
\text { construction latrine: security }\end{array}$ & 51 & 10 & $20 \%$ & 15 & 2 & $13 \%$ & 91 & 20 & $22 \%$ & 28 & 4 & $14 \%$ \\
\hline $\begin{array}{l}\text { Main reason for } \\
\text { construction latrine: hygiene }\end{array}$ & 51 & 17 & $33 \%$ & 15 & 5 & $33 \%$ & 91 & 43 & $47 \%$ & 28 & 10 & $36 \%$ \\
\hline $\begin{array}{l}\text { Main reason for } \\
\text { construction latrine: OD is } \\
\text { harmful }\end{array}$ & 51 & 5 & $10 \%$ & 15 & 1 & $7 \%$ & 91 & 9 & $10 \%$ & 28 & 5 & $18 \%$ \\
\hline $\begin{array}{l}\text { Child stools properly } \\
\text { disposed of [2] }\end{array}$ & 817 & 581 & $71 \%$ & 792 & 515 & $65 \%$ & 1,055 & 781 & $74 \%$ & 1,460 & 993 & $68 \%$ \\
\hline $\begin{array}{l}\text { Community-level open } \\
\text { defecation before } \\
\text { intervention }\end{array}$ & 817 & $28 \%$ & $27 \%$ & 792 & $41 \%$ & $33 \%$ & 1,055 & $28 \%$ & $28 \%$ & 1,460 & $32 \%$ & $31 \%$ \\
\hline
\end{tabular}


medRxiv preprint doi: https://doi.org/10.1101/2021.05.21.21257546; this version posted May 28, 2021. The copyright holder for this preprint (which was not certified by peer review) is the author/funder, who has granted medRxiv a license to display the preprint in perpetuity.

All rights reserved. No reuse allowed without permission.

\begin{tabular}{|l|c|c|c|c|c|c|c|c|c|c|c|c|}
\hline $\begin{array}{l}\text { Community-level open } \\
\text { defecation after intervention }\end{array}$ & 817 & $14 \%$ & $21 \%$ & 792 & $16 \%$ & $21 \%$ & 1,055 & $9 \%$ & $17 \%$ & 1,460 & $13 \%$ & $20 \%$ \\
\hline Environmental hygiene & & & & & & & & & & & & \\
\hline Child stools left in the open & 817 & 147 & $18 \%$ & 792 & 170 & $21 \%$ & 1,055 & 160 & $15 \%$ & 1,460 & 315 & $22 \%$ \\
\hline $\begin{array}{l}\text { Child play environment } \\
\text { observed to be free of } \\
\text { animals }\end{array}$ & 817 & 182 & $22 \%$ & 792 & 187 & $24 \%$ & 1,055 & 261 & $25 \%$ & 1,460 & 294 & $20 \%$ \\
\hline $\begin{array}{l}\text { Child play environment } \\
\text { observed to be free of } \\
\text { garbage/HH waste }\end{array}$ & 817 & 298 & $36 \%$ & 792 & 290 & $37 \%$ & 1,055 & 419 & $40 \%$ & 1,460 & 567 & $39 \%$ \\
\hline $\begin{array}{l}\text { Child play environment } \\
\text { observed to be free of sharp } \\
\text { objects }\end{array}$ & 817 & 449 & $55 \%$ & 792 & 427 & $54 \%$ & 1,055 & 639 & $61 \%$ & 1,460 & 818 & $56 \%$ \\
\hline $\begin{array}{l}\text { Child play environment } \\
\text { observed to be free of feces }\end{array}$ & 817 & 313 & $38 \%$ & 792 & 304 & $38 \%$ & 1,055 & 448 & $42 \%$ & 1,460 & 555 & $38 \%$ \\
\hline
\end{tabular}

Mean LAZ in the control arm was -1.04 (SD 1.20). Compared with control, children in the nutrition-only arm were taller by a mean of $0.08 \mathrm{LAZ}(95 \% \mathrm{CI}-0.01-0.18)$, and children in the combined-intervention arm were taller by $0.10 \mathrm{LAZ}$ (95\% CI 0.01-0.20), although these differences were not observed in the adjusted analyses (Table 5, Figure 2). Children in the nutrition-only arm and combined-intervention arm were heavier than children in the control arm by a mean of 0.10 WAZ (95\% CI 0.00-0.19) and 0.11 (95\% CI 0.03-0.20), respectively. These differences were slightly attenuated in the adjusted analyses (Table 5). No differences were observed between the control arm and intervention arm in terms of WHZ.

Compared to children in the standalone intervention arms, children in the combined intervention arm were taller and heavier than children in the sanitation-only arm, with children in the sanitation-only arm averaging -0.16 LAZ (95\% CI -0.27- -0.04) and -0.10 WAZ (-0.20- -0.01) compared to children in the control arm. These differences were attenuated in the adjusted analysis, and we only observed an adjusted mean difference of -0.13 LAZ (95\% CI -0.23- -0.02) in the sanitation-only arm compared to the combined intervention arm (Table 5). 
medRxiv preprint doi: https://doi.org/10.1101/2021.05.21.21257546; this version posted May 28, 2021. The copyright holder for this preprint (which was not certified by peer review) is the author/funder, who has granted medRxiv a license to display the preprint in perpetuity.

All rights reserved. No reuse allowed without permission.

Table 5: Effects of interventions on height/length and weight (Primary outcome (LAZ) and secondary outcomes (WAZ, WHZ))

\begin{tabular}{|c|c|c|c|c|c|c|c|}
\hline & & & & \multicolumn{2}{|c|}{ Compared to control arm } & \multicolumn{2}{|c|}{ Compared to combined intervention arm } \\
\hline & $\mathrm{N}$ & Mean & SD & $\begin{array}{l}\text { Unadjusted mean } \\
\text { difference }(95 \% \\
\text { CI) }\end{array}$ & $\begin{array}{l}\text { Adjusted mean } \\
\text { difference }(95 \% \\
\text { CI) }\end{array}$ & $\begin{array}{l}\text { Unadjusted mean } \\
\text { difference }(95 \% \mathrm{CI})\end{array}$ & $\begin{array}{l}\text { Adjusted mean } \\
\text { difference }(95 \% \\
\text { CI) }\end{array}$ \\
\hline \multicolumn{8}{|l|}{ LAZ } \\
\hline Nutrition-only & 798 & -0.95 & 1.16 & $0.08(-0.01,0.18)$ & $0.09(-0.01,0.19)$ & $-0.02(-0.12,0.09)$ & $0.01(-0.09,0.11)$ \\
\hline Sanitation-only & 777 & -1.09 & 1.23 & $-0.05(-0.16,0.05)$ & $-0.05(-0.15,0.05)$ & $-0.16(-0.27,-0.04)$ & $\begin{array}{c}-0.13(-0.23,- \\
0.02)\end{array}$ \\
\hline Combined & 1037 & -0.94 & 1.16 & $0.10(0.01,0.20)$ & $0.08(-0.01,0.17)$ & -- & -- \\
\hline Control & 1443 & -1.04 & 1.20 & -- & -- & -- & -- \\
\hline \multicolumn{8}{|l|}{ WAZ } \\
\hline Nutrition-only & 815 & -0.95 & 1.29 & $0.10(0.00,0.19)$ & $0.10(0.01,0.20)$ & $-0.02(-0.12,0.08)$ & $0.01(-0.08,0.11)$ \\
\hline Sanitation-only & 792 & -1.04 & 1.13 & $0.01(-0.07,0.09)$ & $0.01(-0.07,0.09)$ & $-0.10(-0.20,-0.01)$ & $-0.08(-0.17,0.00)$ \\
\hline Combined & 1044 & -0.94 & 1.11 & $0.11(0.03,0.20)$ & $0.09(0.01,0.17)$ & -- & -- \\
\hline Control & 1452 & -1.05 & 1.10 & -- & -- & -- & -- \\
\hline \multicolumn{8}{|l|}{ WHZ } \\
\hline Nutrition-only & 814 & -0.60 & 1.04 & $0.06(-0.03,0.15)$ & $0.06(-0.02,0.15)$ & $-0.02(-0.12,0.08)$ & $0.00(-0.09,0.09)$ \\
\hline Sanitation-only & 790 & -0.59 & 0.98 & $0.06(-0.02,0.14)$ & $0.05(-0.03,0.13)$ & $-0.02(-0.11,0.07)$ & $-0.01 \quad(-0.10,0.08)$ \\
\hline Combined & 1043 & -0.58 & 1.03 & $0.08(0.00,0.16)$ & $0.06(-0.02,0.14)$ & -- & -- \\
\hline Control & 1452 & -0.65 & 0.98 & -- & -- & -- & -- \\
\hline
\end{tabular}

Compared with the control arm, none of the intervention arms differed in the prevalence of children who experienced stunting, wasting, diarrhea (7-day recall), or mortality. Fewer children in the combined-intervention arm were found to be underweight compared to the control arm (PR 0.82, 95\% CI 0.68-0.99), although these differences were attenuated in the adjusted analysis (Table 6). Comparing the combined intervention arm to the standalone intervention arms, the combined-intervention appeared to be protective of stunting and underweight status (PR 1.2, 95\% CI 1.0-1.5; PR 1.2, 95\% CI 1.0-1.5, respectively); however, these differences were also attenuated in the adjusted analyses (Table 6). 
medRxiv preprint doi: https://doi.org/10.1101/2021.05.21.21257546; this version posted May 28, 2021. The copyright holder for this preprint (which was not certified by peer review) is the author/funder, who has granted medRxiv a license to display the preprint in perpetuity. All rights reserved. No reuse allowed without permission.

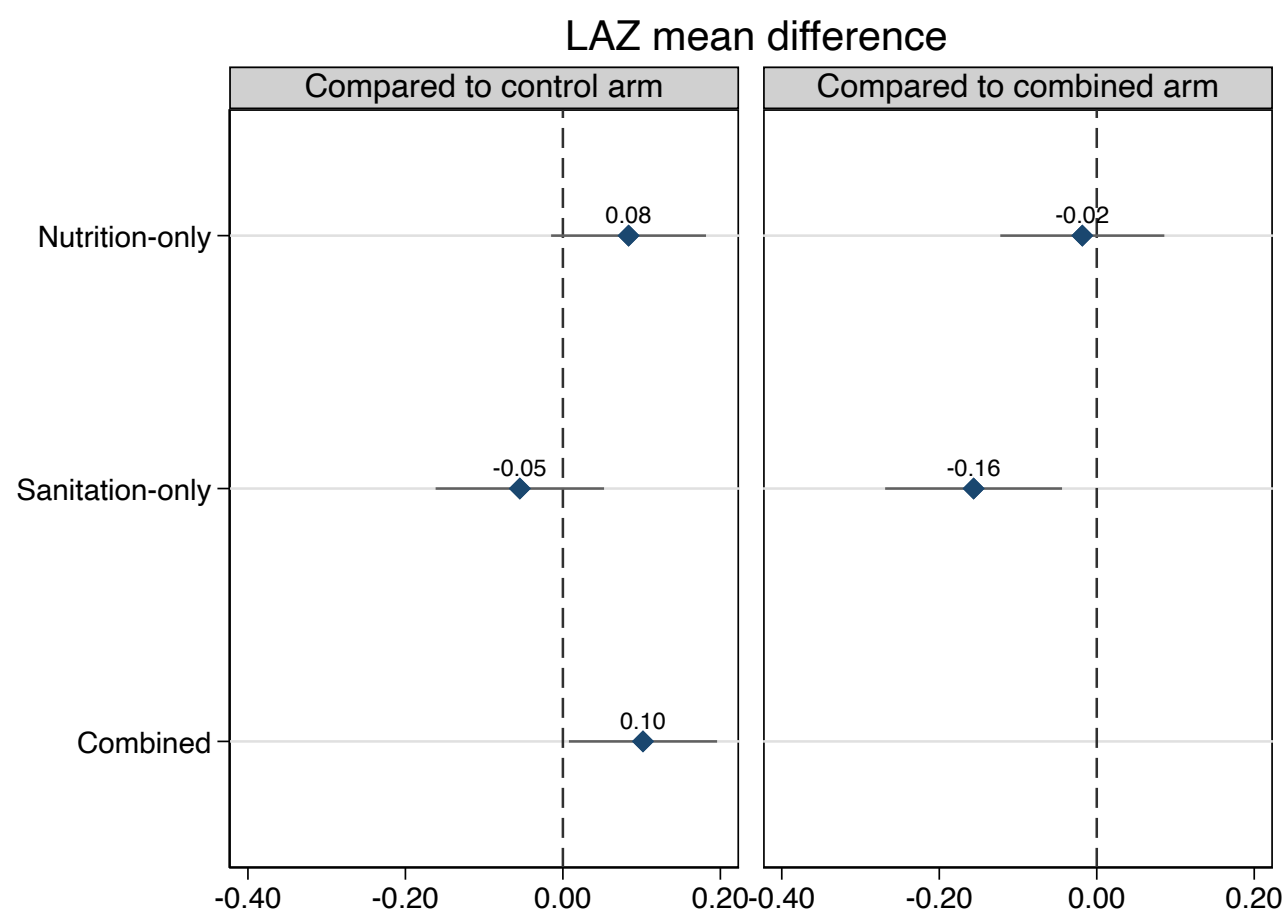

Figure 2: Unadjusted intervention effects on LAZ. Data are mean differences (point) with 95\% CIs (line) 
medRxiv preprint doi: https://doi.org/10.1101/2021.05.21.21257546; this version posted May 28, 2021. The copyright holder for this preprint (which was not certified by peer review) is the author/funder, who has granted medRxiv a license to display the preprint in perpetuity.

All rights reserved. No reuse allowed without permission.

Table 6: Effects of intervention on child health outcomes

\begin{tabular}{|c|c|c|c|c|c|c|c|}
\hline & & & & \multicolumn{2}{|c|}{ Compared to control arm } & \multicolumn{2}{|c|}{$\begin{array}{l}\text { Compared to combined-intervention } \\
\text { arm }\end{array}$} \\
\hline & $\mathrm{N}$ & Mean & $\mathrm{SD}$ & PR $(95 \% \mathrm{CI})$ & aPR $(95 \% \mathrm{CI})$ & PR $(95 \% \mathrm{CI})$ & aPR $(95 \% \mathrm{CI})$ \\
\hline \multicolumn{8}{|l|}{ Stunted } \\
\hline Nutrition-only & 801 & 0.15 & 0.36 & $0.84(0.69,1.03)$ & $0.83(0.68,1.02)$ & $0.93(0.74,1.15)$ & $0.90(0.72,1.12)$ \\
\hline Sanitation-only & 782 & 0.21 & 0.40 & $1.12(0.94,1.33)$ & $1.11(0.94,1.31)$ & $1.23(1.02,1.49)$ & $1.20(0.99,1.46)$ \\
\hline Combined & 1046 & 0.17 & 0.37 & $0.91(0.76,1.09)$ & $0.92(0.77,1.10)$ & -- & -- \\
\hline Control & 1449 & 0.18 & 0.39 & -- & -- & -- & -- \\
\hline \multicolumn{8}{|l|}{ Wasted } \\
\hline Nutrition-only & 815 & 0.07 & 0.26 & $0.87(0.65,1.17)$ & $0.85(0.63,1.14)$ & $1.12(0.80,1.57)$ & $1.09(0.78,1.52)$ \\
\hline Sanitation-only & 790 & 0.07 & 0.26 & $0.84(0.62,1.14)$ & $0.83(0.61,1.13)$ & $1.08(0.76,1.53)$ & $1.06(0.75,1.51)$ \\
\hline Combined & 1052 & 0.07 & 0.25 & $0.78(0.58,1.04)$ & $0.78(0.58,1.05)$ & -- & -- \\
\hline Control & 1457 & 0.08 & 0.28 & -- & -- & -- & -- \\
\hline \multicolumn{8}{|l|}{ Underweight } \\
\hline Nutrition-only & 816 & 0.15 & 0.35 & $0.85(0.71,1.03)$ & $0.84(0.69,1.02)$ & $1.04(0.84,1.29)$ & $0.99(0.80,1.24)$ \\
\hline Sanitation-only & 792 & 0.17 & 0.38 & $1.00(0.85,1.19)$ & $1.00(0.85,1.17)$ & $1.22(1.00,1.49)$ & $1.18(0.97,1.44)$ \\
\hline Combined & 1053 & 0.14 & 0.35 & $0.82(0.68,0.99)$ & $0.84(0.70,1.01)$ & -- & -- \\
\hline Control & 1457 & 0.17 & 0.38 & -- & -- & -- & -- \\
\hline \multicolumn{8}{|c|}{ Diarrhea (7-day recall) } \\
\hline Nutrition-only & 788 & 0.19 & 0.39 & $0.89(0.74,1.06)$ & $0.90(0.76,1.08)$ & $0.95(0.78,1.14)$ & $0.96(0.80,1.16)$ \\
\hline Sanitation-only & 752 & 0.21 & 0.41 & $0.99(0.84,1.17)$ & $0.98(0.83,1.16)$ & $1.05(0.88,1.25)$ & $1.05(0.87,1.25)$ \\
\hline Combined & 1018 & 0.20 & 0.40 & $0.94(0.80,1.11)$ & $0.94(0.79,1.11)$ & -- & -- \\
\hline Control & 1411 & 0.21 & 0.41 & -- & -- & -- & -- \\
\hline \multicolumn{8}{|l|}{ All-cause mortality } \\
\hline Nutrition-only & 1574 & 0.03 & 0.16 & $1.55(0.71,3.39)$ & -- & $1.61(0.68,3.82)$ & -- \\
\hline Sanitation-only & 1636 & 0.03 & 0.16 & $1.09(0.50,2.40)$ & -- & $1.13(0.48,2.68)$ & -- \\
\hline Combined & 1932 & 0.03 & 0.16 & $0.96(0.44,2.10)$ & -- & -- & -- \\
\hline Control & 2688 & 0.03 & 0.16 & -- & -- & -- & -- \\
\hline
\end{tabular}

\section{Discussion}

There was no evidence for an effect of the sanitation intervention on linear growth in young children ( $<28$ months) 28 months after the intervention. There were measured gains in child linear growth in the arms receiving nutrition programming, both delivered independently and in combination with sanitation programming. We found a marginal effect in growth from the nutrition-only programming and a clear effect from the combined programming that was likely attributable to the nutrition programming. The lack of a clear difference in linear growth between 
medRxiv preprint doi: https://doi.org/10.1101/2021.05.21.21257546; this version posted May 28, 2021. The copyright holder for this preprint (which was not certified by peer review) is the author/funder, who has granted medRxiv a license to display the preprint in perpetuity.

All rights reserved. No reuse allowed without permission.

the nutrition-only arm and the combined intervention arm is also consistent with a conclusion that observed linear growth gains were largely attributable to the nutrition programming, further suggesting that the addition of this sanitation programming to nutrition programming did not produce synergistic effects. Intermediate outcomes of meal frequency and dietary diversity did not appear to differ between arms, so effects may be attributable to other elements of the nutrition or combined programming not captured by these measures.

Our findings from this effectiveness trial are consistent with results from several recent randomized factorial WASH and nutrition efficacy trials reporting protective effects of combined/integrated interventions and null effects of WASH on child growth outcomes ${ }^{6,7,21}$. A small number of experimental trials ${ }^{42,43}$ and a larger number of observational studies ${ }^{18-}$ $20,25,28,29,44,45$ have reported increases in child growth and reductions in stunting prevalence with improvements in sanitation coverage and commensurate reductions in OD; among the latter, unmeasured confounding is a likely explanation for observed effects. Unlike clinical randomized controlled trials where populations can be reasonably assumed to hold constant over time and setting, these assumptions often do not hold true for community-based trials where unmeasured factors may inhibit effects and/or may diminish the ability to measure effects of the intervention ${ }^{46}$.

There were differences in frequency and intensity of contact from program promoters across intervention arms, possibly resulting in reduced impact of relatively light-touch sanitation programming. Arms receiving nutrition intervention participated in monthly activities, whereas arms receiving sanitation intervention participated in one triggering session with a few follow-up visits. The lower frequency in contact may explain the discrepancy in intervention compliance rates, with those in the sanitation-only arm reporting CLTS participation rates no different from the control arm (6\% and 6\%), compared with self-reported CLTS participation in the nutrition and combined arms (14\% and 25\%; Table 4). The high self-reported CLTS participation in the nutrition-only arm compared to the control arm may reflect biases embedded in the self-reporting process, especially when considering how long ago the CLTS interventions took place (28+ months ago) and how infrequently CLTS contact occurred relative to nutrition programming. Households that already had access to sanitation may not have engaged with the CLTS programming, the survey respondent may not have been aware of or may not recall specific activities, or other reporting biases could have played a role. The greater frequency and intensity of contact between the interventions and the respondents in the nutrition arms may have resulted in greater apparent recall of programming of any kind in this arm, exposing the possibility of reporting and observer biases. Participants were not masked to interventions due to the nature of the intervention. We included observable indicators in addition to self-reported measures as indicators of intervention compliance, which included direct observations of sanitation facilities and domestic hygiene status (e.g., feces in the play environment of children).

It is possible that this trial's sanitation intervention did not adequately address transmission routes for enteric pathogens. For example, only $22 \%$ of households in our survey were observed to have a child play environment free of animals with little difference between treatment and control arms; this is a transmission pathway that our trial and many other WASH trials have not addressed ${ }^{47}$. The trial design is predicated on the theory that gains in sanitation coverage may lead to improved growth outcomes in children via reductions in the transmission of enteric 
medRxiv preprint doi: https://doi.org/10.1101/2021.05.21.21257546; this version posted May 28, 2021. The copyright holder for this preprint (which was not certified by peer review) is the author/funder, who has granted medRxiv a license to display the preprint in perpetuity.

All rights reserved. No reuse allowed without permission.

infection and disease, though links between sanitation coverage and specific outcomes are poorly understood in high-burden settings. The identification of threshold effects - i.e., that meeting a certain level of sanitation coverage or OD can lead to transformative change and reduction in community-level exposures to enteric pathogens remains unknown.

Sanitation gains attributable to the sanitation intervention were modest when comparing sanitation coverage from our endline survey with the pre-intervention survey in the same communes in 2016 (Supplemental Information). This study found community-level OD estimates of 32\% (IQR 59\%) in the control arm and 41\% (IQR 61\%) in the sanitation-only arm, compared to our post-intervention survey which found community-level OD of $13 \%$ (IQR 29\%) in the control arm and 16\% (IQR 32\%) in the sanitation-only arm, highlighting the strong secular trend of sanitation coverage in Cambodia. An ancillary analysis of impacts of community-level sanitation gains on child linear growth will be performed in the near future. This trend in Cambodia has been documented in other studies: the percentage of all children younger than five years of age with access to an improved sanitation facility, from nationally representative DHS survey data, was $5 \%$ in $2000,17 \%$ in $2005,29 \%$ in 2010 , and $54 \%$ in the most recent DHS survey from $2014^{18,39}$. Corresponding increases in rural areas specifically have also been rapid. From 2010 to 2014, access to any sanitation facility increased from $30 \%$ to $44 \%$ and improved sanitation coverage increased from $27 \%$ to $43 \%{ }^{18,39}$. The pace of development in WASH generally in rural Cambodia means that measuring the impact of specific programs can be challenging. Because of the lack of clear sanitation coverage increases in the study arms receiving the sanitation intervention compared with the nutrition and control arms, this trial is limited in determining the effects of such changes on outcomes.

This trial was also limited in its capacity to measure intervention impacts due to the use of a single cross-sectional survey to retrospectively assess interventions delivered over the previous 28 months. This study included children born from 28 months before up to one month before the final measurement, with the primary outcome variable of age-adjusted linear growth on a continuous scale. As a result, children differed in the amount of time spent exposed to the intervention (including time spent in utero $^{2}$ ), the age at which they are measured, and "maturity" of the interventions to which they are exposed. Extending the study timeline was not possible, though subsequent follow-up to assess longer-term impacts would be valuable. Additionally, this trial was not designed to detect effects that may not be realized until later on in a child's life, so we are unable to capture possible catch-up growth patterns, potential reversal of child growth faltering by rapid linear growth ${ }^{48}$ over 24 months of age. So, while a focus on the first 1,000 days is justified ${ }^{2}$, investigation of growth and growth-promoting factors after this window may provide insight on improved WASH practices.

There are a few key observations from this trial that should be considered in future effectiveness trials of comparable scale. Increased frequency, duration, and intensity of intervention programming could have resulted in greater uptake of sanitation in target communes. Additionally, investments in sanitation programs may be most valuable in settings where there is not already a strong secular trend in expanding sanitation coverage and where open defecation is common; despite the sanitation gains observed in the sanitation-only arm, much of which may have been as a result of the sanitation programming, we were unable to attribute beneficial effects of the sanitation programming due to the high sanitation gains also observed in the 
medRxiv preprint doi: https://doi.org/10.1101/2021.05.21.21257546; this version posted May 28, 2021. The copyright holder for this preprint (which was not certified by peer review) is the author/funder, who has granted medRxiv a license to display the preprint in perpetuity.

All rights reserved. No reuse allowed without permission.

control arm. Finally, we need to define and implement WASH interventions that focus on the overall goal of reducing contact with all feces, including animal feces, and may require more holistic strategies to lower exposures in high-burden settings ${ }^{42,46}$. This may also include the addition of objective supplemental outcome measures or intermediate measures of environmental contamination and disease etiology. Nutrition programming (as delivered in this trial) was effective in promoting linear growth in children. We found no evidence that this sanitation programming delivered in this context provides synergistic effects on growth outcomes, though our observations are limited to settings with increases in sanitation greater than the increases observed in the control arm where coverage estimates were increased from $68 \%$ (preintervention) to $87 \%$ (post-intervention).

\section{Other Information}

\section{Trial Registry}

The trial is registered with ISRCTN Registry (ISRCTN77820875).

\section{Protocol}

The National Ethics Committee for Health Research in the Cambodian Ministry of Health reviewed and approved the protocols (NECHR \#110) prior to the start of data collection. The study also received approvals from the Institutional Review Board at Georgia Institute of Technology (Ref: H19286) and from New England IRB (IRB\#: 120190186).

\section{Funding}

This study was funded by the United States Agency for International Development (USAID). The contents of this manuscript do not necessarily reflect the views of USAID. The contents of this publication are the sole responsibility of the authors and do not necessarily reflect the views of USAID or the United States Government. 
medRxiv preprint doi: https://doi.org/10.1101/2021.05.21.21257546; this version posted May 28, 2021. The copyright holder for this preprint (which was not certified by peer review) is the author/funder, who has granted medRxiv a license to display the preprint in perpetuity.

\section{References}

1. Prendergast, A. J. \& Humphrey, J. H. The stunting syndrome in developing countries. Paediatrics and international child health 34, 250-265 (2014).

2. Victora, C. G. et al. Maternal and child undernutrition: consequences for adult health and human capital. The Lancet 371, 340-357 (2008).

3. de Onis, M. \& Blössner, M. The World Health Organization Global Database on Child Growth and Malnutrition: methodology and applications. International Journal of Epidemiology 32, 518-526 (2003).

4. Black, R. E. et al. Maternal and child undernutrition: global and regional exposures and health consequences. The Lancet 371, 243-260 (2008).

5. Dewey, K. G. \& Adu-Afarwuah, S. Systematic review of the efficacy and effectiveness of complementary feeding interventions in developing countries. Maternal \& child nutrition 4 Suppl 1, 24-85 (2008).

6. Luby, S. P. et al. Effects of water quality, sanitation, handwashing, and nutritional interventions on diarrhoea and child growth in rural Bangladesh: a cluster randomised controlled trial. The Lancet Global Health 6, e302-e315 (2018).

7. Null, C. et al. Effects of water quality, sanitation, handwashing, and nutritional interventions on diarrhoea and child growth in rural Kenya: a cluster-randomised controlled trial. The Lancet Global Health 6, e316-e329 (2018).

8. Ruel, M. T. \& Alderman, H. Nutrition-sensitive interventions and programmes: how can they help to accelerate progress in improving maternal and child nutrition? Lancet (London, England) 382, 536-551 (2013).

9. Dangour, A. D. et al. Interventions to improve water quality and supply, sanitation and hygiene practices, and their effects on the nutritional status of children. Cochrane Database of Systematic Reviews CD009382 (2013) doi:10.1002/14651858.CD009382.pub2.

10. Cumming, O.\& Cairncross, S. Can water, sanitation and hygiene help eliminate stunting? Current evidence and policy implications. Maternal \& Child Nutrition 12, 91105 (2016).

11. Prüss-Ustün, A. et al. Burden of disease from inadequate water, sanitation and hygiene for selected adverse health outcomes: An updated analysis with a focus on low- and middle-income countries. International Journal of Hygiene and Environmental Health 222, 765-777 (2019).

12. Guerrant, R. L., Schorling, J. B., McAuliffe, J. F. \& de Souza, M. A. Diarrhea as a cause and an effect of malnutrition: diarrhea prevents catch-up growth and malnutrition increases diarrhea frequency and duration. The American journal of tropical medicine and hygiene 47, 28-35 (1992).

13. Checkley, W. et al. Multi-country analysis of the effects of diarrhoea on childhood stunting. International journal of epidemiology 37, 816-830 (2008).

14. Papier, K. et al. Childhood Malnutrition and Parasitic Helminth Interactions. Clinical Infectious Diseases 59, 234-243 (2014).

15. Haghighi, P., Wolf, P. L. \& Durie, P. Tropical Sprue and Subclinical Enteropathy: A Vision for the Nineties. Critical Reviews in Clinical Laboratory Sciences 34, 313-341 (1997). 
medRxiv preprint doi: https://doi.org/10.1101/2021.05.21.21257546; this version posted May 28, 2021. The copyright holder for this preprint (which was not certified by peer review) is the author/funder, who has granted medRxiv a license to display the preprint in perpetuity. All rights reserved. No reuse allowed without permission.

16. Humphrey, J. H. Child undernutrition, tropical enteropathy, toilets, and handwashing. Lancet (London, England) 374, 1032-1035 (2009).

17. Budge, S., Parker, A. H., Hutchings, P. T. \& Garbutt, C. Environmental enteric dysfunction and child stunting. Nutrition reviews 77, 240-253 (2019).

18. Ikeda, N., Irie, Y. \& Shibuya, K. Determinants of reduced child stunting in Cambodia: analysis of pooled data from three demographic and health surveys. Bulletin of the World Health Organization 91, 341-349 (2013).

19. Rah, J. H., Sukotjo, S., Badgaiyan, N., Cronin, A. A. \& Torlesse, H. Improved sanitation is associated with reduced child stunting amongst Indonesian children under 3 years of age. Maternal \& Child Nutrition 16, e12741 (2020).

20. Spears, D. How Much International Variation in Child Height Can Sanitation Explain? World Bank Policy Research Working Paper No. 6351 (2013).

21. Humphrey, J. H. et al. Independent and combined effects of improved water, sanitation, and hygiene, and improved complementary feeding, on child stunting and anaemia in rural Zimbabwe: a cluster-randomised trial. The Lancet Global Health 7, e132-e147 (2019).

22. Kar, K. Practical guide to triggering community-led total sanitation (CLTS). (2005).

23. Venkataramanan, V., Crocker, J., Karon, A. \& Bartram, J. Community-Led Total Sanitation: A Mixed-Methods Systematic Review of Evidence and Its Quality. Environmental Health Perspectives 126, 026001 (2018).

24. Kar, K. \& Chambers, R. Handbook on community-led total sanitation. (2008).

25. Vyas, S., Kov, P., Smets, S. \& Spears, D. Disease externalities and net nutrition: Evidence from changes in sanitation and child height in Cambodia, 2005-2010. Economics \& Human Biology 23, 235-245 (2016).

26. Spears, D. Exposure to open defecation can account for the Indian enigma of child height. Journal of Development Economics 146, 102277 (2020).

27. Harris, M., Alzua, M. L., Osbert, N. \& Pickering, A. Community-Level Sanitation Coverage More Strongly Associated with Child Growth and Household Drinking Water Quality than Access to a Private Toilet in Rural Mali. Environmental science \& technology 51, 7219-7227 (2017).

28. Larsen, D. A., Grisham, T., Slawsky, E. \& Narine, L. An individual-level meta-analysis assessing the impact of community-level sanitation access on child stunting, anemia, and diarrhea: Evidence from DHS and MICS surveys. PLOS Neglected Tropical Diseases 11, e0005591 (2017).

29. Fink, G., Günther, I. \& Hill, K. The effect of water and sanitation on child health: evidence from the demographic and health surveys 1986-2007. International Journal of Epidemiology 40, 1196-1204 (2011).

30. Pickering, A. J., Djebbari, H., Lopez, C., Coulibaly, M. \& Alzua, M. L. Effect of a community-led sanitation intervention on child diarrhoea and child growth in rural Mali: A cluster-randomised controlled trial. The Lancet Global Health 3, e701-e711 (2015).

31. Briceño, B., Coville, A., Gertler, P. \& Martinez, S. Are there synergies from combining hygiene and sanitation promotion campaigns: Evidence from a large-scale clusterrandomized trial in rural Tanzania. PloS one 12, e0186228-e0186228 (2017).

32. Cameron, L., Olivia, S. \& Shah, M. Scaling up sanitation: Evidence from an RCT in Indonesia. Journal of Development Economics 138, 1-16 (2019). 
medRxiv preprint doi: https://doi.org/10.1101/2021.05.21.21257546; this version posted May 28, 2021. The copyright holder for this preprint

(which was not certified by peer review) is the author/funder, who has granted medRxiv a license to display the preprint in perpetuity.

All rights reserved. No reuse allowed without permission.

33. Clasen, T. et al. Effectiveness of a rural sanitation programme on diarrhoea, soiltransmitted helminth infection, and child malnutrition in Odisha, India: a clusterrandomised trial. The Lancet Global Health 2, e645-e653 (2014).

34. Patil, S. R. et al. The Effect of India's Total Sanitation Campaign on Defecation Behaviors and Child Health in Rural Madhya Pradesh: A Cluster Randomized Controlled Trial. PLOS Medicine 11, e1001709 (2014).

35. Marschner, I. C. Optimal design of clinical trials comparing several treatments with a control. Pharmaceutical Statistics 6, 23-33 (2007).

36. Cogill, B. Anthropometric Indicators Measurement Guide. (2001).

37. Rustein, S. O. Steps to constructing the new DHS wealth index. (2015).

38. World Health Organization. Indicators for assessing infant and young child feeding practicies. Part I: Definitions. (2008).

39. National Institute of Statistics, Directorate General for Health, and I. I. Cambodia Demographic and Health Survey 2014.

40. VanderWeele, T. J. Principles of confounder selection. European Journal of Epidemiology 34, 211-219 (2019).

41. Rheingans, R., Anderson, J. D., Luyendijk, R. \& Cumming, O. Measuring disparities in sanitation access: does the measure matter? Tropical Medicine \& International Health 19, 2-13 (2014).

42. Pickering, A. J. et al. The WASH Benefits and SHINE trials: interpretation of WASH intervention effects on linear growth and diarrhoea. The Lancet Global Health 7, e1139e1146 (2019).

43. Hammer, J. \& Spears, D. Village sanitation and child health: Effects and external validity in a randomized field experiment in rural India. Journal of Health Economics $\mathbf{4 8 ,}$ 135-148 (2016).

44. Checkley, W. et al. Effect of water and sanitation on childhood health in a poor Peruvian peri-urban community. The Lancet 363, 112-118 (2004).

45. Barnard, S. et al. Impact of Indian Total Sanitation Campaign on Latrine Coverage and Use: A Cross-Sectional Study in Orissa Three Years following Programme Implementation. PLOS ONE 8, e71438 (2013).

46. Cumming, O. et al. The implications of three major new trials for the effect of water, sanitation and hygiene on childhood diarrhea and stunting: a consensus statement. $B M C$ Medicine 17, 173 (2019).

47. Prendergast, A. J. et al. Putting the \&\#x201c;A\&\#x201d; into WaSH: a call for integrated management of water, animals, sanitation, and hygiene. The Lancet Planetary Health 3, e336-e337 (2019).

48. Leroy, J. L., Ruel, M., Habicht, J.-P. \& Frongillo, E. A. Using height-for-age differences (HAD) instead of height-for-age z-scores (HAZ) for the meaningful measurement of population-level catch-up in linear growth in children less than 5 years of age. $B M C$ Pediatrics 15, 145 (2015). 